\title{
PERKEMBANGAN USAHA MIKRO KECIL (UMK) DI PROVINSI JAWA BARAT TAHUN 2006 - 2016
}

\author{
(DEVELOPMENT OF MICRO SMALL ENTERPRISES IN WEST JAVA \\ PROVINCE 2006 - 2016)
}

\begin{abstract}
Oleh:
Anggraita Primatami ${ }^{1)}$, Nanda Hidayati ${ }^{2}$

Sekolah Tinggi Ilmu Ekonomi IPWI Jakarta1,2)

anggraitami@gmail.com ${ }^{1)}$; nanda.assalaam@gmail.com²)

Submit: 01 Dec 2019 Review: 22 Dec 2019 Accept: 26 Dec $2019 \quad$ Publish: Dec 2019

ABSTRACT

Micro small enterprises (MSEs) are an economic sector that is capable of empowering and building community economic independence. This study aims to determine the growth and the role of MSEs in absorption of labor in West Java Province during 2006-2016. This research is a qualitative research with descriptive analysis. The result showed that MSEs had increased during 2006-2016. The highest growth rate of MSEs achieved by Banjar City by $91 \%$ and the lowest achieved by Ciamis Regency by 11\%. In terms of labor absorption, MSEs in West Java had a large role during 2006-2016. The highest absorption of labor is in the wholesale and retail trade sector by 39,86\% in 2006 and 41,03\% in 2016.
\end{abstract}

Keywords:

MSEs, labor, industrial classification.

\section{ABSTRAK}

Usaha mikro kecil (UMK) merupakan sektor ekonomi yang mampu memberdayakan dan membangun kemandirian ekonomi masyarakat. Tujuan penelitian untuk mengetahui perkembangan UMK di Provinsi Jawa Barat dan peranan UMK dalam penyerapan tenaga kerja di Provinsi Jawa Barat selama kurun waktu 2006-2016. Penelitian ini merupakan penelitian kualitatif dengan analisis deskriptif. Hasil penelitian menunjukkan bahwa selama tahun 2006 hingga 2016, UMK di Propinsi Jawa Barat mengalami peningkatan. Laju pertumbuhan jumlah UMK tertinggi berada di Kota Banjars sebesar $91 \%$ dan terendah di Kabupaten Ciamis sebesar 11\%. Dalam hal penyerapan tenaga kerja, UMK di Provinsi Jawa Barat memiliki peranan besar selama kurun waktu 2006 hingga 2016. Tenaga kerja paling banyak terserap pada sektor perdagangan besar dan eceran sebesar 39,86\% pada tahun 2006 dan 41,03\% pada tahun 2016.

\section{Kata kunci:}

UMK, tenaga kerja, lapangan usaha 


\section{PENDAHULUAN}

Usaha Mikro, Kecil, dan Menengah (UMKM) merupakan salah satu bidang usaha yang dapat berkembang dan konsisten dalam perekonomian nasional. Menurut Basri (2003), UMKM di Indonesia bertahan di masa krisis ekonomi disebabkan oleh empat hal, yaitu: (1) UMKM sebagian besar menghasilkan barang konsumsi (consumer goods) tidak tahan lama, (2) Aspek pendanaan mayoritas UMKM lebih mengandalkan non-banking financing, (3) UMKM melakukan spesialisasi produk yang ketat dalam memproduksi barang atau jasa tertentu saja, dan (4) Munculnya UMKM baru imbas dari banyaknya terjadi pemutusan hubungan kerja di sektor formal.

UMKM menjadi wadah yang baik bagi penciptaan lapangan pekerjaan yang produktif. Hal ini dikarenakan UMKM merupakan usaha yang bersifat padat karya dan tidak membutuhkan persyaratan tertentu seperti tingkat pendidikan dan keahlian (keterampilan) pekerja. Usaha skala kecil di Indonesia menyerap sekitar 97\% tenaga kerja (Data dari Kementerian Koperasi dan Usaha Kecil dan Menengah 2019). Ini berarti tenaga kerja di Indonesia bekerja sebagian besar bekerja di sektor UMKM dan sisanya sekitar 3\% saja yang bekerja di sektor usaha besar.

Kontribusinya yang besar terhadap penyerapan tenaga kerja menunjukkan bahwa UMKM mempunyai peran penting di dalam pembangunan dan pertumbuhan ekonomi baik di negara berkembang maupun di negara maju. UMKM berkontribusi terhadap pembentukan dan pertumbuhan Produk Domestik Bruto (PDB) paling besar dibandingkan kontribusinya dari usaha besar (Tambunan, 2012).
Pengembangan UMKM berdasar visi dan arah pembangunan jangka panjang tahun 2005-2025 diarahkan untuk berkembang menjadi pelaku ekonomi yang berkeunggulan kompetitif melalui perkuatan kewirausahaan dan peningkatan produktivitas didukung dengan upaya peningkatan kemampuan adaptasi terhadap kebutuhan pasar, pemanfaatan hasil temuan inovasi dan penerapan teknologi. Pengembangan UMKM menjadi bagian integral dalam perubahan struktur (transformasi structural) sejalan dengan modernisasi agribisnis dan agroindustry untuk mendukung ketahanan pangan, perkuatan basis produksi dan daya saing industry melalui pola pengembangan klaster, percepatan alih teknologi, dan peningkatan kualitas SDM.

Sementara itu, pengembangan usaha mikro menjadi salah satu pilihan strategis Pemerintah untuk mengurangi kesenjangan pendapatan dan kemiskinan (Bappenas, 2019). Pemilihan usaha mikro sebagai pilihan strategis penanggulangan kemiskinan dikarenakan sektor ini lebih cenderung banyak digeluti oleh masyarakat berpendapatan rendah. Oleh karena itu, penelitian ini memfokuskan pada perkembangan sektor Usaha Mikro Kecil (UMK) dan peranannya terhadap penyerapan tenaga kerja di Jawa Barat.

\section{TUJUAN PENELITIAN}

Penelitian ini dilakukan dengan tujuan sebagai berikut:

1. Mengetahui perkembangan UMK di Provinsi Jawa Barat tahun 2006 sampai dengan tahun 2016;

2. Mengetahui peranan UMK terhadap penyerapan tenaga kerja di Provinsi Jawa Barat tahun 2006 sampai dengan tahun 2016. 


\section{TELAAH LITERATUR Definisi UMK}

Sesuai Undang-Undang nomor 20 tahun 2008 mengenai Usaha Mikro, Kecil dan Menengah, definisi dari UMK adalah sebagai berikut:

1. Usaha mikro merupakan suatu usaha produktif yang dimiliki atau dikuasai orang perorangan dan/atau badan usaha perorangan sesuai kriteria usaha dalam kategori mikro yang diatur dalam Undang-Undang.

2. Usaha kecil merupakan usaha ekonomi produktif mandiri atau berdiri sendiri, baik oleh orang perorangan maupun badan usaha, serta bukan merupakan anak atau cabang perusahaan dari usaha menengah atau usaha besar sesuai dengan kriteria usaha kecil yang diatur dalam Undang-Undang.

Berdasarkan kriteria kekayaan dan hasil penjualan, menurut Undang-Undang Nomor 20 tahun 2008 pasal 6, kriteria usaha mikro yaitu:

a. Paling banyak mempunyai jumlah kekayaan bersih sebesar Rp 50.000.000,00, tidak termasuk tanah dan bangunan tempat usaha;

b. Paling banyak mempunyai jumlah hasil penjualan tahunan sebesar $\mathrm{Rp}$ 300.000.000,00.

Kriteria usaha kecil adalah sebagai berikut:

a. Mempunyai kekayaan bersih antara Rp50.000.000,00 sampai dengan Rp500.000.000,00, tidak termasuk tanah dan bangunan tempat usaha;

b. Mempunyai hasil penjualan tahunan antara Rp300.000.000,00 sampai dengan Rp2.500.000.000,00.

\section{Tantangan UMK}

Perkembangan UMK tidak selalu berjalan lancar, ada beberapa hambatan yang membuat UMK sulit berkembang. Menurut Tambunan (2012), beberapa masalah yang menjadi hambatan tersebut yaitu:

1. Terbatasnya modal dan akses dari sumber dan lembaga keuangan.

2. Masih rendahnya kualitas SDM pelaku usaha.

3. Kemampuan pemasaran yang terbatas.

4. Akses informasi usaha yang masih rendah.

5. Distribusi dan pengadaan bahan baku dan input lainnya

6. Biaya tinggi akibat prosedur administrasi dan birokrasi yang kompleks.

\section{Penyerapan Tenaga Kerja}

Menurut Kuncoro (2002), penyerapan tenaga kerja adalah banyaknya lapangan kerja yang sudah terisi yang tercermin dari banyaknya jumlah penduduk bekerja. Penduduk yang bekerja terserap dan tersebar di berbagai sektor perekonomian. Terserapnya penduduk bekerja disebabkan oleh adanya permintaan akan tenaga kerja. Oleh karena itu, penyerapan tenaga kerja dapat dikatakan sebagai permintaan tenaga kerja. Adapun usaha perluasan lapangan pekerjaan untuk menyerap tenaga kerja dapat dilakukan dengan dua cara yaitu:

a. Pengembangan industri yaitu jenis industri yang sifatnya padat karya yang dapat menyerap relative banyak tenaga kerja dalam industri termasuk industri rumah tangga.

b. Melalui berbagai proyek pekerjaan umum, misalnya pembuatan saluran air, bendungan, dan jembatan.

\section{Perkembangan dan Peranan UMK}

Penelitian yang dilakukan oleh Relawan (2014) terkait dengan perkembangan UMK menemukan bahwa UMK di Provinsi Jawa Barat mengalami peningkatan selama tahun 2010 hingga 
2012. Tahun 2010 jumlah UMK sebanyak 8,723 juta unit, sementara di tahun 2011 meningkat menjadi 8,743 juta unit dan di tahun 2012 menjadi 9,159 juta unit. Sementara itu, kontribusi sektor UMK pada penyerapan tenaga kerja di Provinsi Jawa Barat mencapai sebesar $80 \%$ dari total seluruh tenaga kerja. Penyerapan tenaga kerja tersebut mengalami peningkatan dari tahun 2010 hingga 2012. Pada tahun 2010 menyerap sebanyak 12,964 ribu orang, tahun 2011 sebanyak 13,173 ribu orang, dan tahun 2012 sebanyak 13,962 ribu orang. Kontribusi sektor UMK terhadap PDRB Provinsi Jawa Barat juga diketahui cukup tinggi yaitu sebesar $42,78 \%$ dan terhadap laju pertumbuhan ekonomi berkontribusi sebesar 2,95\%.

Pada penelitian lain, Hafni dan Rozali (2015) menemukan bahwa UMKM memiliki peranan yang sangat besar dalam penyerapan tenaga kerja di Indonesia. Hasil penelitian dibagi menjadi dua sektor yaitu penyerapan tenaga kerja pada sektor usaha kecil dan penyerapan tenaga kerja pada sektor usaha mikro. Penelitian menyimpulkan bahwa di Provinsi Jawa Barat, sektor usaha kecil memiliki kontribusi terbesar dalam penyerapan tenaga kerja jika dibandingkan provinsi lain di Indonesia, yaitu sebanyak 1.839.995 orang. Sementara pada sektor usaha mikro, penyerap tenaga kerja terbesar adalah Provinsi Jawa Timur, yaitu sebesar 4.097.229 orang. Secara umum, dari penelitian selama tahun 1996 - 2006, diketahui jumlah usaha mikro dan kecil di Provinsi Jawa Barat sebanyak 451.396 unit dengan menyerap tenaga kerja sebanyak 1.131.791 orang.

\section{METODE PENELITIAN}

Penelitian ini merupakan penelitian kualitatif dengan analisis deskriptif. Jenis dan sumber data yang digunakan adalah data sekunder yang diperoleh dari Badan Pusat Statistik (BPS) yang meliputi data hasil Sensus Ekonomi sepuluh tahunan, yaitu tahun 2006 dan 2016. Objek dalam penelitian ini adalah UMK Provinsi Jawa Barat. Metode yang digunakan dalam pengumpulan data adalah studi pustaka dan observasi. Sedangkan metode analisis data yang digunakan dalam penelitian ini meliputi reduksi data, penyajian data, dan penarikan kesimpulan.

\section{HASIL DAN PEMBAHASAN}

Sektor Usaha Mikro Kecil (UMK) menjadi sektor yang dominan dan memegang peranan penting terhadap perekonomian di Jawa Barat dibandingkan dengan sektor lain yaitu Usaha Menengah Besar (UMB). Kondisi ini terlihat dari jumlah usaha di Jawa Barat tahun 2016. Pada tahun 2016, jumlah usaha di Jawa Barat sebanyak 4.634.807 unit dengan perincian 4.564 .958 unit atau 98,5\% sektor UMK dan 69.849 unit atau 1,5\% adalah sektor UMB yang tersebar di seluruh wilayah Provinsi Jawa Barat (BPS, 2017).

Tabel 1

Jumlah Sektor Usaha Jawa Barat 2016

\begin{tabular}{|l|r|}
\hline Sektor Usaha & \multicolumn{1}{|c|}{2016} \\
\hline Usaha mikro kecil & 4.564 .958 \\
\hline Usaha menengah besar & 69.849 \\
\hline Total & 4.634 .807 \\
\hline
\end{tabular}

Sumber: BPS, 2017

Berdasarkan tabel 2, dapat diketahui bahwa jumlah UMK di Provinsi Jawa Barat meningkat selama tahun 2006 hingga tahun 2016. Jumlah UMK di Provinsi Jawa Barat secara keseluruhan mengalami peningkatan sebesar 51\%, yaitu dari 3.011.214 unit pada tahun 2006 menjadi 4.545.874 unit pada tahun 2016. Hal ini sejalan dengan hasil penelitian Relawan (2014) yang menyatakan bahwa jumlah UMK di Jawa Barat semakin meningkat selama tahun 2010 hingga 2012. 
Tahun 2006, jumlah UMK terbanyak berada di Kabupaten Bandung sebesar 303.326 unit atau $10,1 \%$ dari keseluruhan UMK di Provinsi Jawa Barat, sedangkan paling sedikit berada di Kota Banjar, yaitu sebesar 13.346 unit atau 0,44\%. Selama kurun waktu 10 tahun hingga tahun 2016, Kabupaten Bandung tidak dapat mempertahankan posisinya dalam kepemilikan UMK terbanyak di Provinsi Jawa Barat. Jumlah UMK terbanyak pada tahun 2016 berada di Kabupaten Bogor sebanyak 367.271 unit $(8,08 \%)$, sedangkan jumlah UMK paling sedikit masih berada di Kota Banjar sebanyak 25.455 unit $(0,55 \%)$. Hal tersebut menunjukkan bahwa sektor UMK di Kabupaten Bogor dapat berkembang baik selama 10 tahun dari tahun 2006 hingga 2016 dibandingkan di kabupaten/kota lain di Jawa Barat.

Tabel 2

Perkembangan UMK Provinsi Jawa Barat

\begin{tabular}{|l|r|r|c|}
\hline Kabupaten/Kota & \multicolumn{1}{|c|}{$\mathbf{2 0 0 6}$} & \multicolumn{1}{c|}{$\mathbf{2 0 1 6}$} & Pertumbuhan \\
\hline Bogor & 256.972 & 367.271 & $43 \%$ \\
\hline Sukabumi & 162.314 & 266.729 & $64 \%$ \\
\hline Cianjur & 163.723 & 249.061 & $52 \%$ \\
\hline Bandung & 303.326 & 347.573 & $15 \%$ \\
\hline Garut & 168.844 & 258.314 & $53 \%$ \\
\hline Tasikmalaya & 137.541 & 186.398 & $36 \%$ \\
\hline Ciamis & 123.581 & 137.301 & $11 \%$ \\
\hline Kuningan & 61.204 & 92.647 & $51 \%$ \\
\hline Cirebon & 141.383 & 249.823 & $77 \%$ \\
\hline Majalengka & 103.988 & 154.638 & $49 \%$ \\
\hline Sumedang & 81.127 & 114.550 & $41 \%$ \\
\hline Indramayu & 120.533 & 186.738 & $55 \%$ \\
\hline Subang & 102.499 & 168.017 & $64 \%$ \\
\hline Purwakarta & 51.353 & 84.537 & $65 \%$ \\
\hline Karawang & 159.955 & 229.031 & $43 \%$ \\
\hline Bekasi & 159.711 & 227.110 & $42 \%$ \\
\hline Bandung Barat & & 154.904 & - \\
\hline Pangandaran & & 59.527 & - \\
\hline Kota Bogor & 66.938 & 83.138 & $24 \%$ \\
\hline Kota Sukabumi & 25.867 & 38.841 & $50 \%$ \\
\hline Kota Bandung & 230.697 & 330.314 & $43 \%$ \\
\hline Kota Cirebon & 28.741 & 38.485 & $34 \%$ \\
\hline Kota Bekasi & 135.115 & 193.215 & $43 \%$ \\
\hline Kota Depok & 102.296 & 157.744 & $54 \%$ \\
\hline Kota Cimahi & 35.630 & 55.723 & $56 \%$ \\
\hline Kota Tasikmalaya & 74.530 & 88.790 & $19 \%$ \\
\hline Kota Banjar & 13.346 & 25.455 & $91 \%$ \\
\hline TOTAL & 3.011 .214 & 4.545 .874 & $51 \%$ \\
\hline & & & \\
\hline
\end{tabular}

Sumber: Sensus Ekonomi tahun 2006 dan 2016
Peningkatan jumlah UMK juga terjadi di seluruh kabupaten/kota yang berada di Provinsi Jawa Barat. Hal dapat dilihat dari level pertumbuhan jumlah UMK di setiap kabupaten/kota di Provinsi Jawa Barat selama tahun 2006-2016 yang berada di atas $10 \%$.

Meskipun Kota Banjar memiliki jumlah UMK paling sedikit, tetapi jika dilihat berdasarkan laju pertumbuhan jumlah UMK, Kota Banjar mengalami peningkatan tertinggi dalam kurun waktu 2006 hingga 2016. Laju pertumbuhan UMK di Kota Banjar sebesar 91\%, dimana sebanyak 13.346 unit pada tahun 2006 dapat tumbuh menjadi 25.455 unit pada tahun 2016. Kemudian disusul oleh Kabupaten Cirebon dengan laju pertumbuhan sebesar $77 \%$, yaitu dari 141.383 unit pada tahun 2006 menjadi 249.823 unit pada tahun 2016.

Sementara itu, laju pertumbuhan UMK terendah berada di Kabupaten Ciamis sebesar 11\%. Di Kabupaten Ciamis, jumlah UMK pada tahun 2006 sebesar 123.581 unit menjadi 137.301 unit pada tahun 2016. Kemudian disusul oleh Kabupaten Bandung dengan laju pertumbuhan sebesar $15 \%$ dari 303.326 unit menjadi 347.573 unit.

Rendahnya laju pertumbuhan UMK di Kabupaten Ciamis dan Kabupaten Bandung dikarenakan adanya pemekaran wilayah di kedua daerah tersebut. Pada tahun 2007 terjadi pemekaran wilayah di Kabupaten Bandung menjadi 2 Kabupaten, yaitu Kabupaten Bandung dan Kabupaten Bandung Barat. Pada tahun 2012 terjadi pemekaran wilayah kembali, yaitu pemekaran wilayah di Kabupaten Ciamis menjadi Kabupaten Ciamis dan Kabupaten Pangandaran.

Berdasarkan gambar 1, terlihat bahwa pada tahun 2006 UMK di Provinsi Jawa Barat yang bergerak pada sektor perdagangan besar dan eceran merupakan 
sektor terbesar, yaitu sebanyak 1.789 .898 unit atau sebesar $42,84 \%$ dari total keseluruhan lapangan usaha. Kemudian disusul sektor transportasi, pergudangan, dan komunikasi sebesar 17,12\%; penyediaan akomodasi dan penyediaan makan minum sebesar 16,32\%; industri pengolahan $10,80 \%$; jasa kemasyarakatan, sosial, budaya, dan perorangan lainnya sebesar $5,78 \%$; real estat, usaha persewaan, dan jasa perusahaan sebesar 3,87\%; jasa pendidikan sebesar 1,25\%; dan sektor lain dengan nilai kurang dari $1 \%$, dimana yang terendah pada sektor listrik, gas, dan air sebesar 751 unit atau $0,02 \%$.

\section{Gambar 1}

Jumlah UMK di Provinsi Jawa Barat

Berdasarkan Lapangan Usaha Tahun 2006

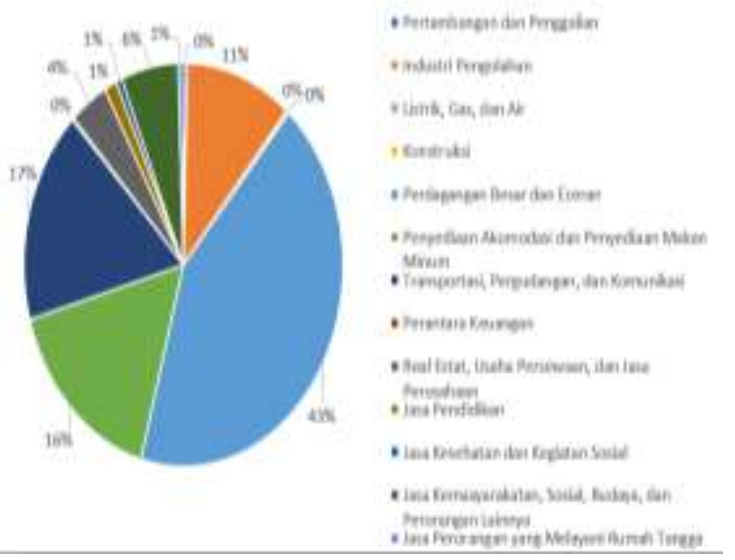

Sumber: Sensus Ekonomi 2006

Gambar 2 menunjukkan bahwa pada tahun 2016 UMK di Provinsi Jawa Barat paling banyak bergerak di sektor perdagangan besar-eceran, reparasiperawatan mobil dan sepeda motor sebanyak 2.156.577 unit atau sebesar $47,44 \%$, disusul sektor penyediaan akomodasi dan penyediaan makan minum sebesar 18,93\%; industri pengolahan sebesar 13,21\%; pengangkutan dan pergudangan sebesar $6,51 \%$; jasa lainnya sebesar 3,98\%; informasi dan komunikasi sebesar 2,67\%; dan sektor lainnya dengan nilai kurang dari 2\%, dimana sektor aktivitas keuangan dan asuransi merupakan sektor dengan jumlah UMK paling sedikit, yaitu sebesar 9.091 unit atau $0,20 \%$.

Gambar 2

Jumlah UMK Provinsi Jawa Barat

Berdasarkan Lapangan Usaha Tahun 2016

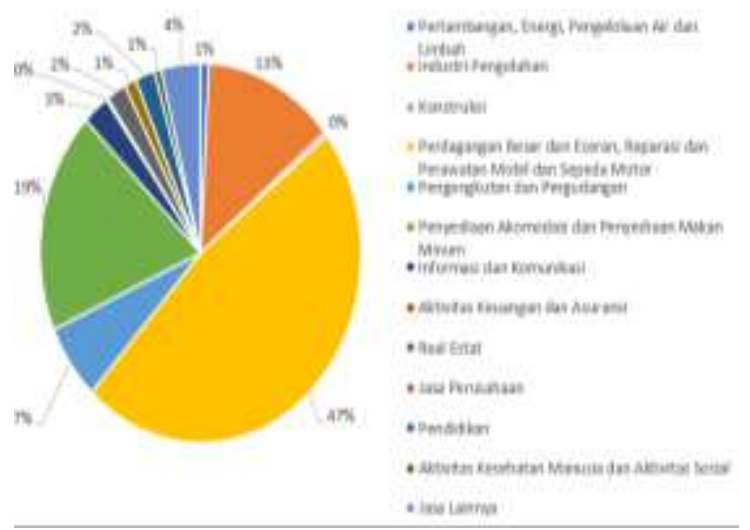

Sumber: Sensus Ekonomi 2016

Kondisi di atas mencerminkan bahwa dalam kurun waktu 2006 hingga 2016, sektor perdagangan besar dan eceran merupakan sektor yang paling diminati pelaku usaha di Provinsi Jawa Barat. Hal ini dapat disebabkan rendahnya hambatan keluar masuk pasar (entry and exit barrier) salah satunya karena rendahnya modal yang diperlukan, terutama pada sektor perdagangan eceran. Rendahnya modal memberikan kemudahan bagi masyarakat khususnya yang memiliki pendapatan rendah untuk berwirausaha di sektor UMK.

Jika dilihat dari penyerapan tenaga kerja, jumlah tenaga kerja yang terserap pada sektor UMK di Provinsi Jawa Barat sebanyak 9.702 .395 orang atau $16,37 \%$ dari total keseluruhan pekerja di sektor UMK di Indonesia. Adapun perinciannya adalah sebanyak 4.081 .642 orang atau $42 \%$ merupakan pekerja yang dibayar dan 5.620 .753 orang atau 58\% merupakan pekerja yang tidak dibayar. Jawa Barat menduduki peringkat kedua setelah Provinsi Jawa Timur dalam penyerapan tenaga kerja pada sektor UMK (BPS, 2017). 
Hal ini sejalan dengan penelitian yang dilakukan oleh Hafni dan Rozali (2015) yang menyatakan bahwa UMKM berperan besar dalam penyerapan tenaga kerja di Indonesia.

\section{Tabel 3}

Penyerapan Tenaga Kerja UMK Provinsi Jawa Barat tahun 2006 - 2016

\begin{tabular}{|l|r|r|c|}
\hline Kabupaten/Kota & \multicolumn{1}{|c|}{$\mathbf{2 0 0 6}$} & \multicolumn{1}{c|}{$\mathbf{2 0 1 6}$} & Pertumbuhan \\
\hline Bogor & \multicolumn{1}{c|}{729.878} & 812.982 & $11 \%$ \\
\hline Sukabumi & 330.406 & 536.086 & $62 \%$ \\
\hline Cianjur & 306.875 & 498.321 & $62 \%$ \\
\hline Bandung & 593.867 & 817.684 & $38 \%$ \\
\hline Garut & 336.766 & 532.463 & $58 \%$ \\
\hline Tasikmalaya & 249.706 & 394.420 & $58 \%$ \\
\hline Ciamis & 239.993 & 287.472 & $20 \%$ \\
\hline Kuningan & 115.137 & 191.341 & $66 \%$ \\
\hline Cirebon & 307.067 & 529.203 & $72 \%$ \\
\hline Majalengka & 188.866 & 324.385 & $72 \%$ \\
\hline Sumedang & 154.519 & 238.430 & $54 \%$ \\
\hline Indramayu & 222.430 & 388.983 & $75 \%$ \\
\hline Subang & 198.054 & 334.081 & $69 \%$ \\
\hline Purwakarta & 83.222 & 180.349 & $117 \%$ \\
\hline Karawang & 269.718 & 500.608 & $86 \%$ \\
\hline Bekasi & 243.445 & 470.179 & $93 \%$ \\
\hline Bandung Barat & & 318.220 & - \\
\hline Pangandaran & & 125.965 & - \\
\hline Kota Bogor & 95.213 & 192.573 & $102 \%$ \\
\hline Kota Sukabumi & 37.019 & 84.555 & $128 \%$ \\
\hline Kota Bandung & 316.907 & 713.214 & $125 \%$ \\
\hline Kota Cirebon & 42.423 & 90.196 & $113 \%$ \\
\hline Kota Bekasi & 210.616 & 414.527 & $97 \%$ \\
\hline Kota Depok & 131.634 & 347.103 & $164 \%$ \\
\hline Kota Cimahi & 54.162 & 116.811 & $116 \%$ \\
\hline Kota Tasikmalaya & 113.834 & 209.193 & $84 \%$ \\
\hline Kota Banjar & 29.117 & 53.051 & $82 \%$ \\
\hline TOTAL & $\mathbf{5 . 6 0 0 . 8 7 4}$ & 9.702 .395 & $\mathbf{7 3} \%$ \\
\hline & & & \\
\hline
\end{tabular}

Sumber: Sensus Ekonomi tahun 2006 dan 2016

Berdasarkan tabel 3, diketahui bahwa penyerapan tenaga kerja pada sektor UMK di Provinsi Jawa Barat mengalami peningkatan selama tahun 2006 hingga 2016. Penyerapan tenaga kerja pada sektor UMK di Provinsi Jawa Barat secara keseluruhan mengalami peningkatan sebesar $73 \%$, yaitu dari 5.600 .874 orang pada tahun 2006 menjadi 9.702 .395 orang pada tahun 2016. Hal ini sejalan dengan hasil penelitian Relawan (2014) yang menyatakan bahwa penyerapan tenaga kerja pada sektor UMK di Jawa Barat mengalami peningkatan selama tahun 2010 hingga 2012.

Peningkatan tersebut juga terjadi pada setiap kabupaten/kota yang berada di Provinsi Jawa Barat. Pada tahun 2006, penyerapan tenaga kerja pada sektor UMK di Provinsi Jawa Barat terbesar berada di Kabupaten Bogor, yaitu sebesar 729.878 orang atau 13,03\% dari total tenaga kerja yang bekerja di UMK Provinsi Jawa Barat. Sementara itu, penyerapan tenaga kerja paling sedikit pada tahun 2006 berada di Kota Banjar, yaitu sebesar 29.117 orang atau $0,52 \%$ dari total penduduk Provinsi Jawa Barat.

Meskipun pada tahun 2016 Kabupaten Bogor memiliki jumlah UMK terbesar di Provinsi Jawa Barat, namun sektor ini tidak menjadi penyerap tenaga kerja terbesar jika dibandingkan dengan kabupaten/kota lain. Dalam kurun waktu 10 tahun hingga tahun 2016, penyerapan tenaga kerja di sektor UMK terbanyak berada di Kabupaten Bandung sebanyak 817.684 orang $(8,42 \%)$, sedangkan penyerapan tenaga kerja paling sedikit masih berada di Kota Banjar sebanyak 53.051 orang $(0,55 \%)$.

Kabupaten Bandung memiliki jumlah penduduk sebesar 3.596.623 orang atau 7,59\% dari total penduduk Provinsi Jawa Barat dengan luas wilayah $1.768 \mathrm{~km} 2$ atau 5,00\% dari total luas wilayah Provinsi Jawa Barat. Sementara itu, Kabupaten Banjar memiliki jumlah penduduk paling sedikit di Provinsi Jawa Barat, yaitu sebesar 181.901 orang atau $0,38 \%$ dengan luas wilayah $113 \mathrm{~km} 2$ atau 0,32\% dari total luas wilayah Provinsi Jawa Barat (BPS Provinsi Jawa Barat, 2017).

Jika dilihat berdasarkan laju pertumbuhan, penyerapan tenaga kerja pada sektor UMK di Provinsi Jawa Barat tertinggi berada di Kota Depok. Laju pertumbuhan penyerapan tenaga kerja di Kota Depok sebesar 164\%, yaitu dari 13.634 orang pada tahun 2006 menjadi 347.103 orang pada tahun 2016. Sementara itu, laju pertumbuhan penyerapan tenaga kerja terendah berada di Kabupaten Bogor meskipun Kabupaten Bogor memiliki jumlah penduduk terbesar di Provinsi 
Jawa Barat, yaitu sebesar 5.587.390 orang atau 11,79\% dari total penduduk Provinsi Jawa Barat (BPS Provinsi Jawa Barat, 2017). Laju pertumbuhan penyerapan tenaga kerja di Kabupaten Bogor hanya sebesar $11 \%$, yaitu dari 729.878 orang pada tahun 2006 menjadi 812.982 orang pada tahun 2016.

\section{Gambar 3}

Penyerapan Tenaga Kerja UMK Provinsi Jawa Barat Berdasarkan Lapangan Usaha Tahun 2006

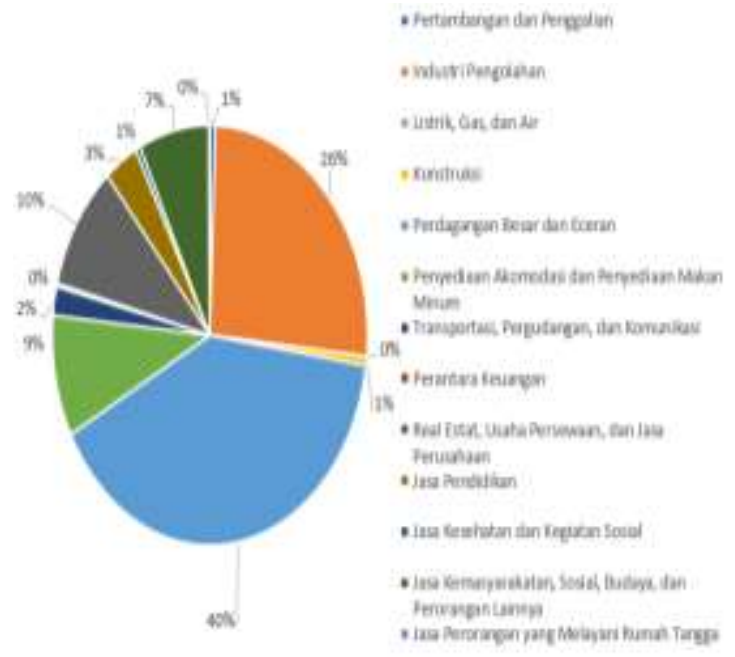

Sumber: Sensus Ekonomi 2006

Berdasarkan gambar 3, pada tahun 2006 sektor usaha UMK di Provinsi Jawa Barat yang paling banyak menyerap tenaga kerja adalah pedagang besar dan eceran. Sebanyak 1.804 .246 orang atau 39,86\% dari total tenaga kerja yang bekerja di UMK Provinsi Jawa Barat berada di sektor pedagang besar dan eceran. Hal ini sejalan dengan besarnya proporsi jumlah UMK di Propinsi Jawa Barat yang bergerak dalam sektor tersebut.

Lalu disusul oleh industri pengolahan sebanyak 1.179.344 orang $(26,05 \%)$; real estat, usaha persewaan, dan jasa perusahaan sebanyak 440.460 orang $(9,73 \%)$; penyediaan akomodasi dan penyediaan makan minum sebanyak 423.828 orang $(7,18 \%)$; jasa kemasyarakatan, sosial, budaya, dan perorangan lainnya sebanyak 324.992 orang $(7,18 \%)$; dan sektor lain yang kurang dari 5\% dengan sektor listrik, gas, dan air merupakan sektor terendah yaitu sebanyak 1.586 orang $(0,04 \%)$.

\section{Gambar 4}

Penyerapan Tenaga Kerja UMK Provinsi Jawa Barat Berdasarkan Lapangan Usaha Tahun 2016
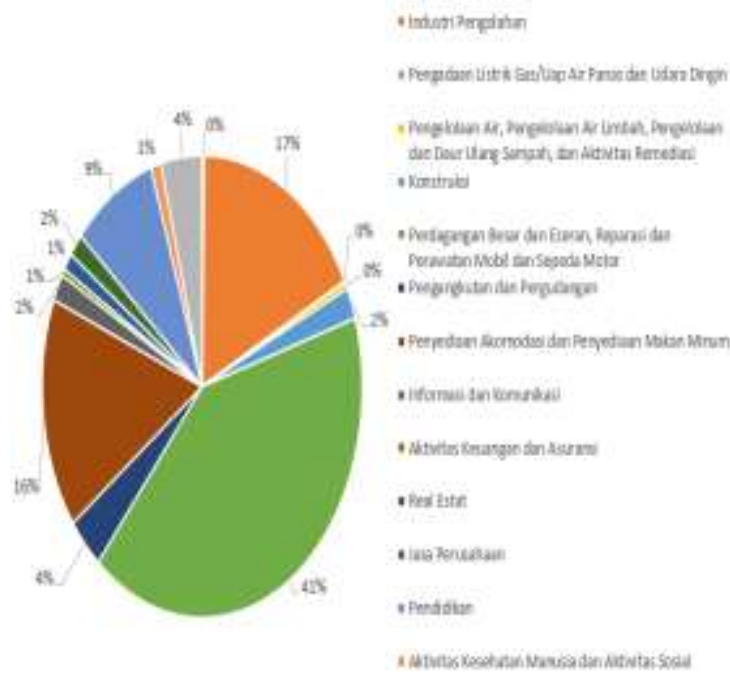

Sumber: Sensus Ekonomi 2016

Pada gambar 4, diketahui bahwa sebanyak 3.981.293 orang (41,03\%) tenaga kerja bekerja pada sektor perdagangan besar dan eceran, reparasi dan perawatan mobil dan sepeda motor. Kemudian disusul oleh industri pengolahan sebanyak 1.673 .252 orang $(17,25 \%)$; penyediaan akomodasi dan penyediaan makan minum sebanyak 1.569 .177 orang $(16,17 \%)$; pendidikan sebanyak 825.579 orang $(8,51 \%)$; dan sisanya sektor lain yang kurang dari 5\%, dimana sektor pertambangan dan penggalian merupakan sektor penyerap tenaga kerja terendah, yaitu sebanyak 19.847 orang $(0,20 \%)$.

Sektor perdagangan besar dan eceran merupakan sektor tertinggi dalam penyerapan tenaga kerja dari tahun 2006 hingga 2016. Banyaknya jumlah UMK di sektor perdagangan besar dan eceran merupakan penyebab tingginya jumlah 
tenaga kerja yang terserap pada sektor ini. Dengan kondisi di atas, dapat diperoleh gambaran bagaimana sektor usaha mikro kecil dapat membawa kontribusi bagi perekonomian masyarakat berpendapatan rendah.

Pemerintah dalam hal ini diharapkan dapat turut berperan mengembangkan usaha mikro kecil antara lain dengan memberikan akses pembiayaan atau modal yang mudah bagi pengusaha mikro kecil dan memfasilitasi pelatihan guna meningkatkan kemampuan pengusaha mikro kecil dalam menjalankan dan mengembangkan usahanya sehingga usaha yang berjalan dapat berkelanjutan dan memberikan kemandirian ekonomi bagi masyarakat khususnya masyarakat berpendapatan rendah.

Keterkaitan sektor UMK secara inklusi juga diperlukan dalam memperkuat keberlangsungan UMK yang dapat diwujudkan dengan penguatan dan kerjasama yang saling terkait antar sesama UMK maupun UMK dengan sektor usaha menengah dan besar. Keberadaan UMK yang bergerak di sektor hulu hingga hilir pada setiap sektor lapangan usaha hendaknya diselaraskan dengan sektor usaha menengah besar sehingga tercipta suatu rantai pasok (supply chain) dan rantai nilai tambah (value chain) yang berkelanjutan.

\section{KESIMPULAN}

1. UMK di Provinsi Jawa Barat selama kurun waktu 2006 hingga 2016 mengalami peningkatan, baik dilihat secara keseluruhan maupun di setiap kabupaten/kota dengan laju pertumbuhan tertinggi berada di Kota Banjar dan terendah di Kabupaten Ciamis.

2. UMK di Provinsi Jawa Barat memiliki peranan besar dalam penyerapan tenaga kerja selama kurun waktu 2006 hingga 2016 dimana tenaga kerja paling banyak terserap pada sektor perdagangan besar dan eceran.

\section{SARAN}

1. Untuk kabupaten/kota yang memiliki tingkat pertumbuhan UMK rendah dapat mencontoh kabupaten/kota yang memiliki pertumbuhan tinggi.

2. Penelitian selanjutnya hendaknya memasukkan data usaha menengah guna melengkapi penelitian sektor UMKM.

3. Penelitian selanjutnya diharapkan dapat membandingkan kondisi UMKM di beberapa daerah sehingga dapat diperoleh gambaran yang lebih luas mengenai kondisi UMKM.

\section{DAFTAR PUSTAKA}

Badan Pusat Statistik. 2007. Hasil Pendaftaran Perusahaan/Usaha: Hasil Sensus Ekonomi 2006, Provinsi Jawa Barat. Jakarta: BPS.

Badan Pusat Statistik. 2017. Hasil Pendaftaran (Listing) Usaha/ Perusahaan Sensus Ekonomi 2016 Provinsi Jawa Barat, No. 30/05/Th. XIX, 24 Mei 2017. Jakarta: BPS.

Badan Pusat Statistik Provinsi Jawa Barat. 2017. Provinsi Jawa Barat dalam Angka 2017. Bandung: BPS Provinsi Jawa Barat.

Basri, Faisal. 2003. Dinamika UKM di Antara Gemuruh Retorika Politik dan Mitos. Seminar Pembangunan Hukum Nasional VIII. Denpasar - Bali

Hafni dan Rozali. 2015. Analisis Usaha Mikro, Kecil, dan Menengah (UMKM) terhadap Penyerapan Tenaga Kerja di Indonesia. Ekonomikawan, Vol. 15 No. 2: 77-96.

Kuncoro, Haryo. 2002. Upah Sistem Bagi Hasildan Penyerapan Tenaga Kerja. Jurnal Ekonomi Pembangunan, Vol 7 Nomor 1: 45-54. 
Relawan. Ida Nurnida. 2014. Peran Kelembagaan Usaha Mikro dan Kecil (UMK) terhadap Laju Pertumbuhan Ekonomi (LPE) Jawa Barat. MIMBAR, Vol. 30, No. 2: 159-170.

Tambunan, Tulus. 2012. Usaha Mikro, Kecil dan Menengah di Indonesia Isu-IsU Penting. Jakarta: Penerbit LP3ES.

Undang- Undang Nomor 20 Tahun 2008 tentang Usaha Mikro, Kecil dan Menengah (UMKM). http://www.depkop.go.id/data-umkm. Perkembangan Data Usaha Mikro, Kecil, Menengah (UMKM) dan Usaha Besar (UB) Tahun 2016-2017, diakses 28 November 2019 pukul 10.00.

https://www.bappenas.go.id/files/1814/20 57/0437/RPJP_2005-2025.pdf, diakses 28 November 2019 pukul 10.35. 